\title{
STUDI ANALISA PENGARUH BEBAN TIMBUNAN TINGGI TERHADAP RASIO PEMAMPATAN TANAH DASAR
}

\author{
Putu Tantri K.Sari, Yudhi Lastiasih \\ Staf pengajar Jurusan Teknik Sipil, Fakultas Teknik Sipil dan Perencanaan, Institut Teknologi Sepuluh \\ Nopember Surabaya. \\ Email: tantrigeoteknik@gmail.com
}

\begin{abstract}
ABSTRAK
Penelitian ini dilakukan untuk mengetahui besarnya pemampatan tanah dasar di kaki timbunan serta untuk mengetahui seberapa besar ratio pemampatan pada kaki timbunan dan sisi timbunan terhadap pemampatan maksimal di tengah timbunan. Besarnya ratio tersebut kemudian dibandingkan antara beberapa variable yaitu jenis tanah dasar,kedalaman tanah dasar lunak, tinggi timbunan dan lebar timbunan. Penelitian ini dilakukan dengan beberapa pendekatan empiris untuk memperoleh nilai Indeks pemampatan $(\mathrm{Cc})$. Nilai Index mengembang (Cs) tanah adalah dibuat variasi antara 1/5-1/10 Cc. Hasil yang diperoleh dari penelitian ini adalah berupa ratio pemampatan tanah dasar dikaki timbunan (a), sisi timbunan (b) dan tengah timbunan (c) . Nilai a/c apabila kedalaman tanah mampu mampat 10 meter adalah 0.22 dan kedalaman tanah mampu mampat 20 meter adalah 0.27 . Nilai b/c apabila kedalaman tanah mampu mampat 10 meter adalah 0.87 dan kedalaman tanah mampu mampat 20 meter adalah 0.82 . Hasil studi menunjukan bahwa ratio $(\mathrm{a} / \mathrm{c})$ adalah $\mathrm{y}=0.0047 \mathrm{x}+0.1729$; ratio $(\mathrm{b} / \mathrm{c})$ adalah $\mathrm{y}=-0.0046 \mathrm{x}$ +0.9121 .
\end{abstract}

Kata kunci: tanah lunak, timbunan jalan, ratio pemampatan

\section{Pendahuluan}

Perhitungan pemampatan tanah di bawah timbunan selalu mengutamakan besar pemampatan pada tengah timbunan saja sebagai besar pemampatan maksimum. Sedangkan pemampatan di kaki timbunan selalu dianggap memiliki nilai nol atau tidak terjadi pemampatan sama sekali. Selain itu, area yang berada beberapa meter dari kaki timbunan juga dianggap sama sekali tidak terjadi pemampatan. Padahal, pemampatan tanah dapat terjadi di area yang terkena pengaruh beban timbunan yang berada tidak tepat di bawah timbunan. Pemampatan tersebut pernah terjadi pada pembangunan timbunan untuk relokasi jalan tol Porong, Sidoarjo, Indonesia. Pemampatan tanah terjadi pada kawasan perumahan penduduk yang berada beberapa meter dari kaki timbunan.

Adanya kemungkinan pemampatan yang bernilai tidak nol di kaki timbunan maupun di area terpengaruh disekitar timbunan tersebut dapat dilihat dari adanya perubahan tegangan di area tersebut (Gambar 1). Berdasarkan rumusan penurunan tanah konsolidasi primer 1 dimensi oleh Terzaghi , besarnya nilai tegangan akibat beban di atasnya dapat mempengaruhi besarnya pemampatan. Sehingga, dapat disimpulkan bahwa pemampatan yang terjadi tepat di kaki timbunan adalah bernilai tidak nol. Besarnya nilai pemampatan tersebut perlu diketahui untuk melihat apakah adanya pemampatan tersebut tidak berdampak buruk terhadap stabilitas timbunan sendiri maupun bangunan disekitar kaki timbunan. Untuk itu perlu dilakukan analisa lebih lanjut untuk menghitung besarnya pemampatan yang terjadi di kaki timbunan dan di area lain yang terkena pengaruh beban timbunan jalan. 


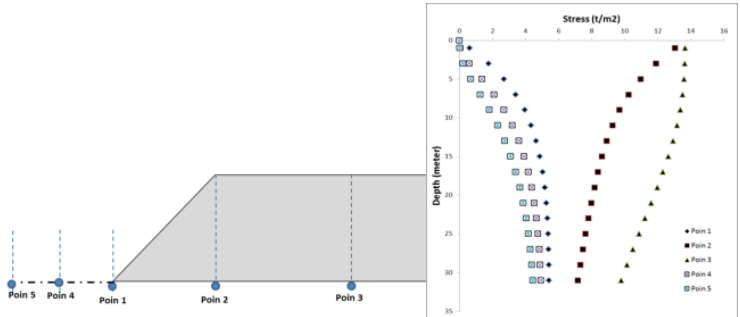

Gambar 1. Besar tegangan yang tidak nol di area sekitar timbunan.

Sebuah peraturan pembangunan jalan di Jepang menyatakan bahwa besar ratio pemampatan tanah di kaki dan sisi timbunan terhadap titik pusat timbunan adalah tidak 0 . Ratio tersebut diperoleh berdasarkan penelitian pada kondisi tanah di Jepang. Pada peraturan tersebut menunjukan bahwa ratio pemampatan tanah dasar di kaki timbunan terhadap tengah timbunan adalah $0.2 \times$ Settlement Consolidation di area tengah timbunan $(0.2 \mathrm{Sc})$, sedangkan ratio pemampatan sisi timbunan terhadap tengah timbunan adalah 0.8Sc. Sari dan Lastiasih (2015) melakukan penelitian untuk mengetahui ratio pemampatan tanah dasar di kaki dan sisi timbunan terhadap tengah timbunan. Penelitian tersebut memperoleh nilai ratio pemampatan kaki timbunan terhadap tengah timbunan sebesar 0.2Sc (kedalaman tanah lunak 10 meter) dan $0.25 \mathrm{Sc}$ (kedalaman tanah lunak 20 meter). Nilai ratio pemampatan sisi timbunan terhadap tengah timbunan sebesar $0.86 \mathrm{Sc}$ (kedalaman tanah lunak 10 meter) dan $0.81 \mathrm{Sc}$ (kedalaman tanah lunak 20 meter). Namun penelitian ini masih dibatasi pada perbandingan nilai Coefficient Swelling (Cs) $=1 / 8$ x Coefficient Consolidation $(\mathrm{Cc})$ saja.

Penelitian lanjutan ini dilakukan untuk mengetahui besarnya pemampatan tanah dasar di kaki timbunan serta untuk mengetahui seberapa besar ratio pemampatan pada kaki timbunan dan sisi timbunan terhadap pemampatan maksimal di tengah timbunan pada berbagai kondisi tanah dasar (Ratio nilai $\mathrm{Cc}$ terhadap Cs adalah $1 / 5 \mathrm{~s} / \mathrm{d} 1 / 10$ ). Besarnya ratio tersebut kemudian dibandingkan antara beberapa variable yaitu jenis tanah,kedalaman tanah lunak, tinggi timbunan dan lebar timbunan. Penelitian ini dilakukan dengan beberapa pendekatan empiris untuk memperoleh nilai Coefficient Consolidation /Indeks pemampatan $(\mathrm{Cc})$. Nilai index pemampatan sangat diperlukan oleh para geoteknik untuk mengetahui besarnya pemampatan dari suatu tanah lempung lunak. Nilai pemampatan tersebut diperlukan untuk melakukan banyak sekali pendesainan. Pendekatan empiris yang dilakukan dalam penelitian ini kemudian disesuaikan dengan kondisi tanah lunak di Surabaya dan sekitarnya.

Banyak sekali rumusan pendekatan empiris yang telah diuji pada jenis tanah lempung lunak dibeberapa negara berkembang. Perumusan empiris tersebut didapatkan dari pengkorelasian nilai-nilai konsistensi dan karakteristik tanah yang lebih mudah diuji dilaboratorium. Beberapa prediksi perumusan empiris berdasarkan nilai Liquid limit telah diuji oleh Skempton (1944); Terzaghi\&Peck (1967) dan Bowles (1979), berdasarkan Platicity Index telah diuji oleh Jian-Hua Yin (1999); AmithNath dan DeDalal (2004) berdasarkan Shringkage Index yang telah diuji oleh Sridharan dan Nagrai (2001). Rumusan-rumusan lain juga sudah banyak diuji dibeberapa Negara antara lain : Azzouz dkk (1976) yang melakukan pengujian tanah lempung Chicago, lempung Brazilian, Lempung Motley dari kota San Paulo dan lempung di USA serta lempung di Greece berdasarkan nilai kadar air, angka pori dan Liquid Limit ; Nacci dkk (1975) yang melakukan pengujian pada lempung di North Atlantic berdasarkan nilai Index plasticity. Bukan hanya itu, puluhan rumusan lainnya juga telah dikembangkan dengan mengkorelasi nilai karakteristik tanah yaitu angka pori, specific Gravity dan kadar air. Beberapa rumusan tersebut diantaranya dikembangkan oleh Azzouz, Krizek and Corotis (1976); Wroth and Wood (1978); Nagaraj dan Murthy (1986;1986); Ostenberg (1972); Cozzolina (1961); Sower (1970); Moran, Proctor, Mueser dan Rutlrdge (1958). Rumusan tersebut ditawarkan untuk seluruh lempung lunak.

Tujuan dari penelitian ini adalah untuk mengetahui besarnya ratio pemampatan tanah dasar yang terjadi di bawah kaki timbunan dan di sisi timbunan terhadap besarnya pemampatan maksimal yang terjadi di tengah timbunan pada semua kondisi tanah. Hasil dari penelitian ini adalah untuk memperoleh rumusan empiris untuk mengetahui ratio pemampatan tanah dasar di bawah timbunan pada berbagai jenis tanah dasar dengan pendekatan empiris serta beberapa variasi kedalaman tanah mampu-mampat, variasi tinggi timbunan dan variasi lebar timbunan jalan. 


\section{Studi Pustaka}

Suatu keadaan tanah yang mengarahkan kepada dua definisi dasar yang didasarkan pada sejarah tegangan :

Terkonsolidasi secara normal (Normally consolidated), dimana tekanan efektif overburden pada saat ini adalah merupakan tekanan maksimum yang pernah dialami oleh tanah itu.

Terlalu terkonsolidasi (Overconsolidated) dimana tekanan efektif overburden pada saat ini adalah lebih kecil dari tekanan yang pernah dialami oleh tanah itu sebelumnya. Tekanan efektif overburden maksimum yang pernah di alami sebelumnya dinamakan tekanan prakonsolidasi (preconsolidated pressure).

Penelitian ini dilakukan dengan mengasumsikan tanah dasar berjenis lempung terlalu terkonsolidasi. Persamaan yang digunakan dalam perhitungan pemampatan pada lempung berjenis terlalu terkonsolidasi lebih adalah sebagai berikut:

$$
\begin{array}{r}
S_{c}=\frac{C_{s} \cdot H}{1+e_{o}} \log \left(\frac{p_{o}+\Delta P}{p_{o}}\right) \\
\quad \text { untuk }\left(\mathrm{p}_{\mathrm{o}}+\Delta \mathrm{p}\right) \leq \mathrm{p}_{\mathrm{c}} \\
S_{C}=\frac{C_{s} \cdot H}{1+e_{o}} \log \frac{p_{c}}{p_{o}}+\frac{C_{c} \cdot H}{1+e_{o}} \log \left(\frac{p_{o}+\Delta P}{p_{c}}\right) \\
\text { untuk } \mathrm{p}_{\mathrm{o}}+\Delta \mathrm{p}>\mathrm{p}_{\mathrm{c}}
\end{array}
$$

\section{III.Metodologi}

Penelitian untuk memperoleh ratio pemampatan tanah dasar di bawah timbunan ini dilakukan dengan beberapa variasi data sebagai pembanding yaitu :

a. Variasi tinggi timbunan ( 3 meter; 5 meter dan 7 meter) dengan kemiringan slope 1:1.

b. Variasi kedalaman tanah dasar lempung lunak mampu-mampat (10 s/d 20 meter)

c. Variasi lebar timbunan jalan $(20 \mathrm{~m}, 30 \mathrm{~m}$ dan 40 meter)

d. Variasi nilai index pemampatan (Cc) dengan menggunakan rumusan empiris Kosasih\&Mochtar (1999); Nishida (1956) dan Showers (1970).

Variasi nilai index pemampatan tanah dasar selain menggunakan rumusan empiris yang tersebut di atas juga menggunakan perbandingan data tanah yang ada di Surabaya. Perbandingan data tanah dari rumusan empiris dilakukan dengan menggunakan 466 sample tanah pada 77 titik bor di 25 lokasi di Surabaya. Data tanah yang digunakan sebagai pembanding ini diperoleh dari Laboratorium Mekanika Tanah dan Batuan, Jurusan Teknik Sipil ITS, Surabaya, Indonesia. Hasil nilai index pemampatan $(\mathrm{Cc})$ dan Angka pori (eo) dapat dilihat pada Gambar 2.

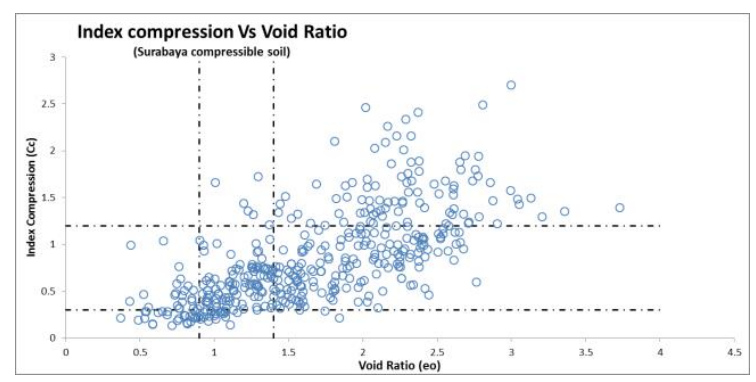

Gambar 2. Grafik nilai index pemampatan dan angka pori dari data tanah di Surabaya.

Dengan menggunakan berbagai variasi di atas kemudian dilakukan analisa untuk mengetahui besarnya peningkatan tegangan tanah dasar akibat beban timbunan. Perhitungan peningkatan nilai tegangan vertikal ini dilakukan untuk mengetahui besarnya pemampatan tanah. Perhitungan peningkatan nilai tegangan vertical dilakukan dengan metode superposisi dan grafik nilai factor pengaruh (influence factor_after Osterberg, 1957).

Rumusan empiris untuk memperoleh nilai plastisitas index $(\mathrm{Cc})$ yang digunakan dalam analisa ini adalah:

$\mathrm{Cc}=0.006 \mathrm{LL}+0.13$ eo $2-0.13$ (oleh Kosasih dan Mochtar (1999) pada lempung lunak di Surabaya dan sekitarnya)

$\mathrm{Cc}=1.15(\mathrm{eo}-0.35)($ oleh Nishida (1956) pada semua jenis lempung)

$\mathrm{Cc}=0.75(\mathrm{eo}-0.50)($ oleh Sowers $(1970)$ untuk jenis tanah yang memiliki nilai plastisitas yang rendah).

Batasan nilai angka pori dan index pemampatan pada penelitian ini adalah 0.9-1.4 untuk angka pori dan 0.3- 1.2 untuk nilai index pemampatan. Batasan nilai tersebut adalah diperoleh dari rumusan empiris untuk tanah lempung anorganik untuk nilai plastisitas sedang hingga tinggi dengan nilai batas cair (LL) yaitu antara 
$30 \%$ hingga $120 \%$. Dengan menggunakan nilai $\mathrm{Cc}$ dan eo tersebut kemudian dilakukan perhitungan untuk mengetahui besarnya pemampatan tanah dasar di bawah timbunan dengan menggunakan rumusan pemampatan 1 dimensi oleh Terzaghi dengan mengasumsikan seluruh tanah dasar berjenis tanah lempung overconsolidated (OC) soil dengan kondisi $\mathrm{po}+\Delta \mathrm{p}>\mathrm{pc}$.

\section{Analisis dan Pembahasan}

\section{IV.1 Analisa awal ratio pemampatan tanah dasar}

Analisa dengan menggunakan variasi yang disebut di atas dilakukan untuk memperoleh rasio pemampatan tanah dasar pada kaki timbunan dan sisi timbunan terhadap tengah timbunan. Analisa dilakukan pada berbagai kondisi dan menghasilkan simpulan yang relative sama (Gambar 3 dan 4) yaitu:

a. Pada kaki timbunan, semakin dalam tanah mampu-mampat maka akan semakin besar ratio pemampatan. Sebaliknya besar ratio pemampatan tanah pada sisi timbunan, semakin dalam tanah mampu-mampat maka akan semakin kecil ratio pemampatan tanahnya. Tren tersebut terjadi pada semua lebar timbunan yang dianalisa.

b. Semakin tinggi timbunan, maka akan semakin besar ratio pemampatan yang terjadi. Ratio pada kaki timbunan tidak terlalu besar perbedaannya jika dibandingkan dengan ratio pada sisi timbunan.

c. Semakin lebar timbunan jalan maka semakin kecil ratio pemampatan yang terjadi, tetapi perbedaan tersebut tidak terlalu siknifikan.
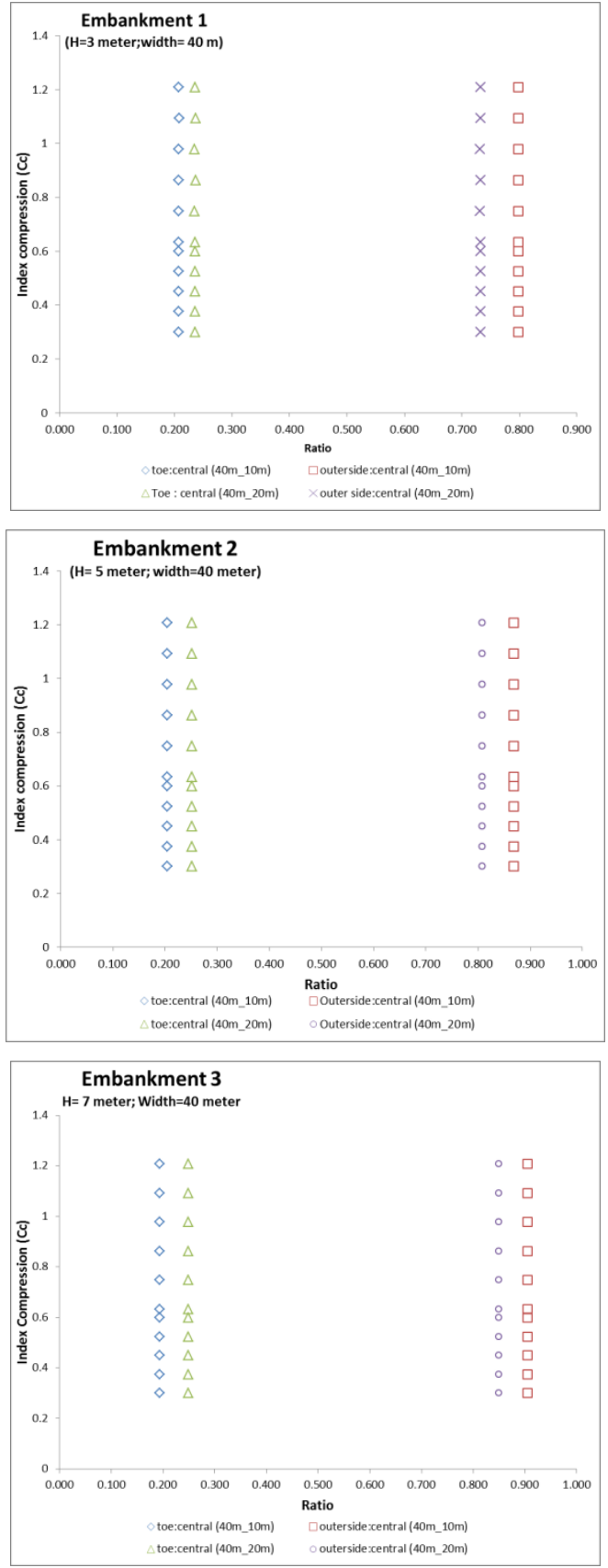

Gambar 3. Hasil analisa ratio pemampatan tanah di bawah timbunan dengan lebar atas 40 meter (a) Ketinggian 3 meter ; (b) Ketinggian 5 meter; (c) Ketinggian 7 meter 

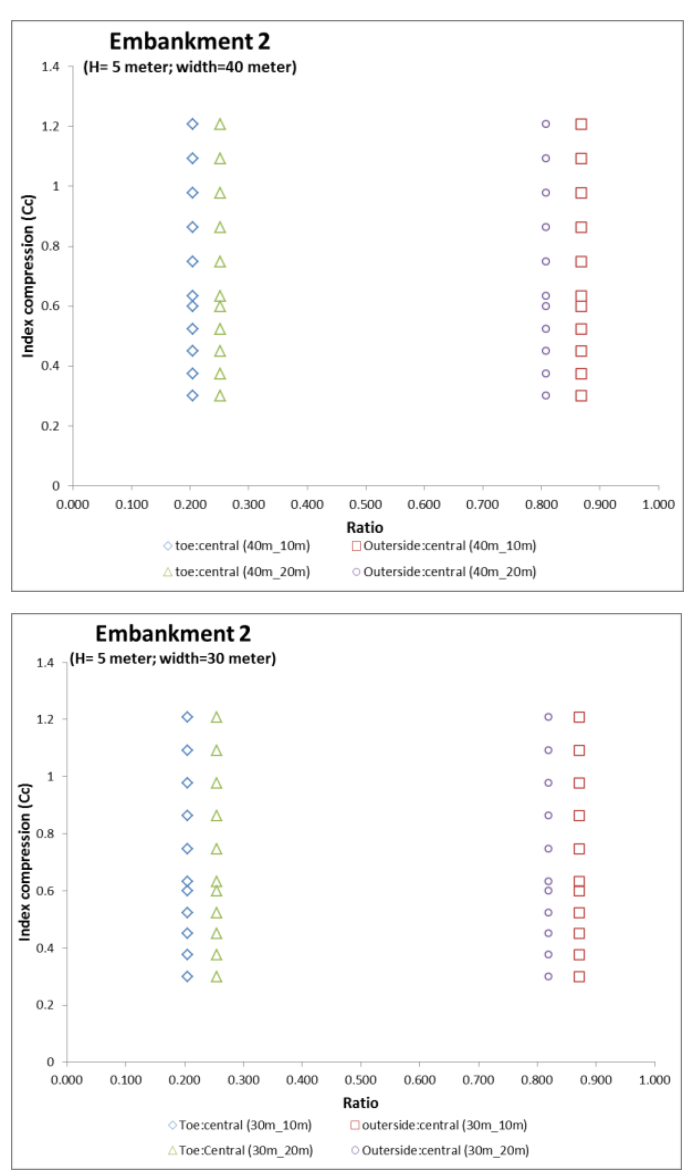

Gambar 4. Hasil analisa ratio pemampatan tanah di bawah timbunan $\mathrm{H}=5$ meter (a) Lebar timbunan 40 meter; (b) Lebar timbunan 30 meter.

Hasil analisa awal pada grafik di atas menunjukkan bahwa besar pemampatan tanah dasar pada kaki timbunan adalah tidak nol, sedangkan besar pemampatan tanah dasar pada sisi timbunan adalah tidak sama dengan besar pemampatan tanah dasar pada tengah timbunan. Berdasarkan ratio pemampatan pada gambar di atas dapat dilihat bahwa terdapat perbedaan besaran ratio antara masing-masing variasi yang digunakan. Untuk itu, perlu dilakukan analisa lanjutan untuk mengetahui seberapa besar pengaruh variasi data tanah dasar maupun timbunan terhadap besarnya ratio pemampatan yang terjadi.

\section{IV.2 Analisa rasio pemampatan tanah dasar di bawah timbunan.}

Perhitungan ratio pemampatan dilakukan sebanyak 396 percobaan. Jumlah percobaan perhitungan dan analisa tersebut dilakukan yaitu dengan 3 variasi ketinggian dan 2 variasi kedalaman tanah mampu mampat. Setiap variasi tersebut dilakukan percobaan perhitungan pada 5 variasi angka pori dan 11 variasi Cc/Cs. Trend grafik hasil analisa dengan beragam variasi yang digunakan dapat dilihat pada Gambar 6 s/d Gambar 9 dengan keterangan dapat dilihat pada Gambar 5.

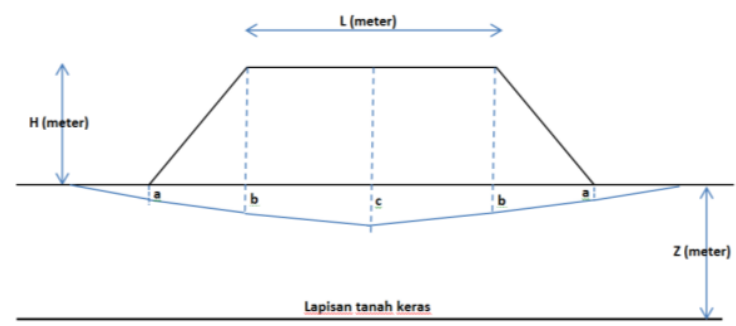

Gambar 5. Keterangan symbol pada analisa ratio pemampatan tanah dasar di bawah timbunan.

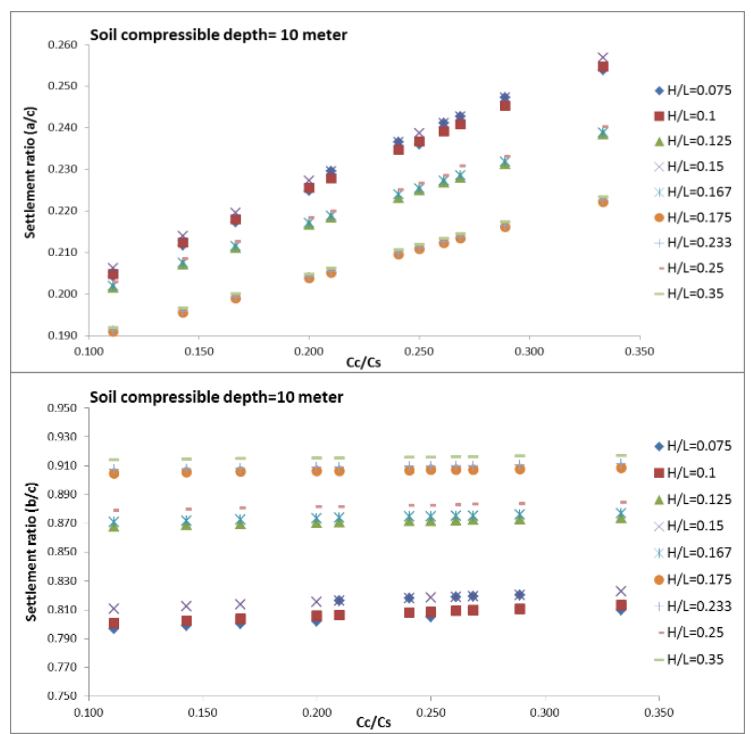

Gambar 6. Ratio pemampatan tanah untuk kedalaman tanah lunak 10 meter.

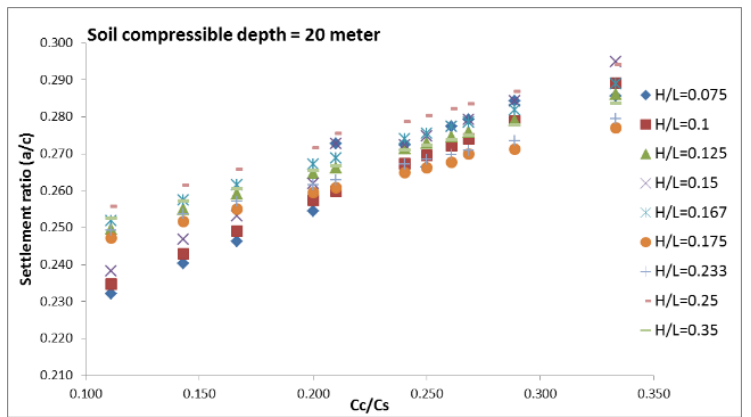

PuEERI STUDI ANALISA PENGARUH BEBAN TIMBUNAN TINGGI TERHADAP RATIO PEMAMPATAN TANAH DASAR

Putu Tantri K. Sari, Yudhi Lastiasih 


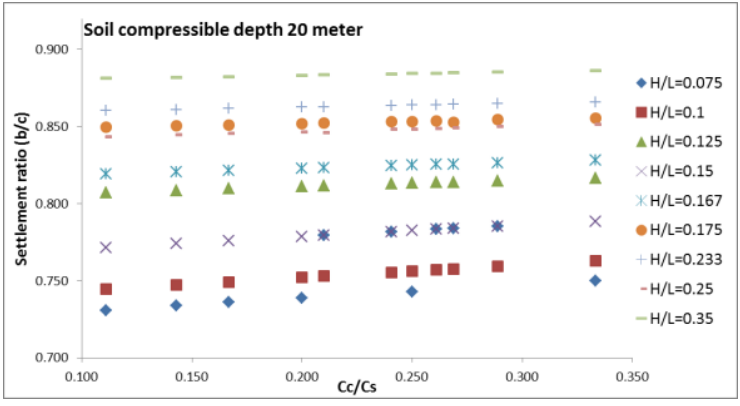

Gambar 7. Ratio pemampatan tanah dasar untuk kedalaman tanah lunak 20 meter.

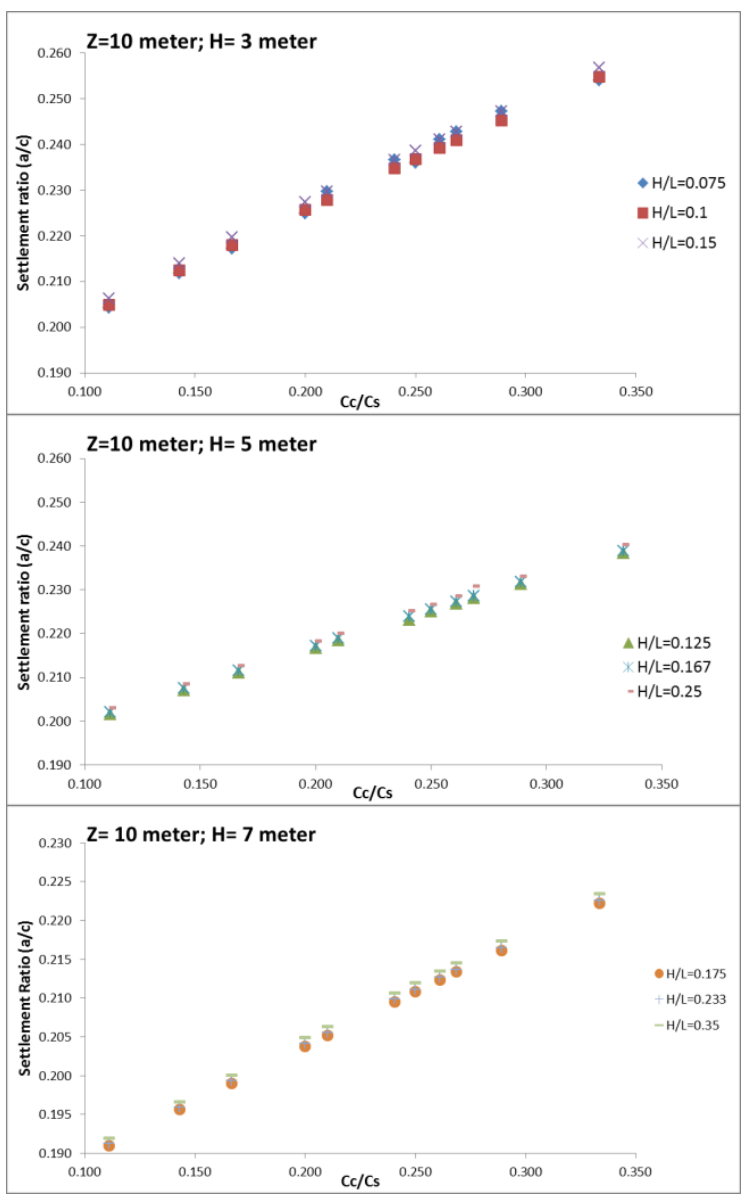

Gambar 8. Ratio pemampatan tanah dasar di kaki timbunan dan tengah timbunan untuk $\mathrm{Z}=10$ meter pada masing-masing ketinggian timbunan. (a) Tinggi timbunan 3 meter; (b) Tinggi timbunan 5 meter; (c) Tinggi timbunan 7 meter.

Sari dan Lastiasih (2015) dalam penelitiannya menyatakan bahwa semakin besar L maka a/c dan b/c akan semakin kecil; Semakin besar Z maka a/c semakin besar; b/c semakin kecil; Semakin besar $\mathrm{H}$ maka a/c akan semakin kecil; $\mathrm{b} / \mathrm{c}$ semakin besar. Hasil yang sama juga diperoleh pada penelitian ini seperti dapat dilihat pada Gambar 6 s/d Gambar 9. Trend grafik yang sama juga diperoleh pada kedalaman tanah lunak (Z) 20 meter seperti pada Gambar 10.

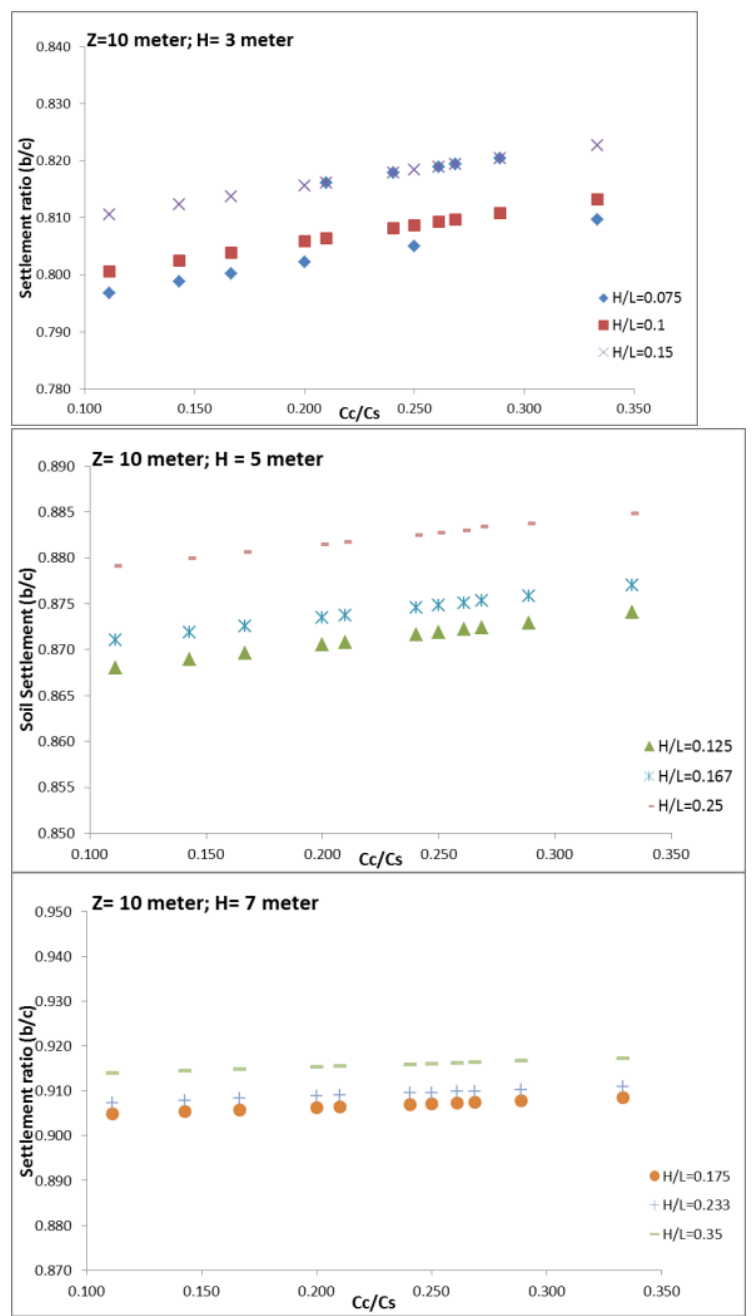

Gambar 9. Ratio pemampatan tanah dasar di sisi timbunan dan tengah timbunan untuk $\mathrm{Z}=$ 10 meter pada masing-masing ketinggian timbunan. (a) Tinggi timbunan 3 meter; (b) Tinggi timbunan 5 meter; (c) Tinggi timbunan 7 meter.

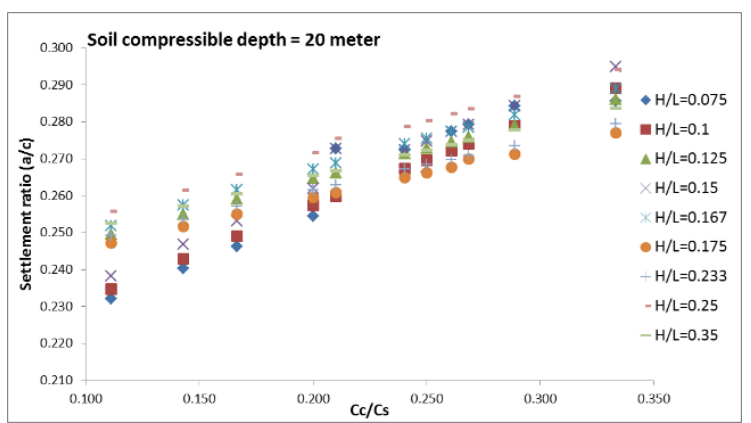




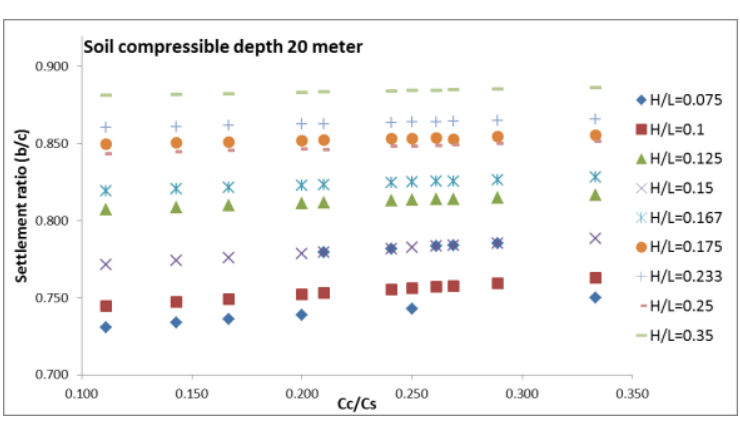

Gambar 10. Ratio pemampatan tanah dasar pada $\mathrm{Z}=20$ meter. a) Rasio pemampatan tanah dasar di kaki timbunan dan tengah timbunan; b) Ratio pemampatan tanah dasar di sisi timbunan dan tengah timbunan.

Besarnya ratio pemampatan tanah dasar di bawah timbunan memiliki hasil yang relative berbeda pada setiap kondisi parameter tanahnya. Namun perbedaan ratio pemampatan tersebut tidak terlalu besar. Pada kondisi $\mathrm{Z}=10$ meter, besar ratio pemampatan $\mathrm{a} / \mathrm{c}$ adalah bervariasi antara 0.19-0.24. Ratio pemampatan pada kondisi yang bervariasi tersebut memiliki coefisien variasi adalah berkisar antara 4-6\%. Nilai variasi tersebut adalah sangat kecil sehingga nilai rata-rata dari banyak data yang ada dapat dijadikan sebagai ratio pemampatan a/c pada tanah dasar di bawah timbunan. Besar koefisien variasi data hasil analisa pemampatan tanah dasar di bawah timbunan dengan berbagai kondisi dapat dilihat pada Tabel 1 .

Tabel 1. Rata-rata nilai ratio pemampatan tanah dasar dibawah timbunan berdasarkan nilai

Koefisien variasi (CV) dari semua variasi data tanh digunakan.

\begin{tabular}{|c|c|c|c|c|}
\hline \multirow{2}{*}{$\mathbf{H} / \mathbf{L}$} & \multicolumn{4}{|c|}{$\mathbf{Z = 1 0}$ meter } \\
\cline { 2 - 5 } & rata-rata a/c & $\mathbf{C V}$ & rata-rata b/c & $\mathbf{C V}$ \\
\hline 0.08 & 0.23 & 6.39 & 0.81 & 1.09 \\
\hline 0.10 & 0.23 & 6.16 & 0.81 & 0.45 \\
\hline 0.13 & 0.22 & 4.74 & 0.87 & 0.20 \\
\hline 0.15 & 0.23 & 6.18 & 0.82 & 0.42 \\
\hline 0.17 & 0.22 & 4.75 & 0.87 & 0.19 \\
\hline 0.18 & 0.21 & 4.28 & 0.91 & 0.12 \\
\hline 0.23 & 0.21 & 4.29 & 0.91 & 0.11 \\
\hline 0.25 & 0.22 & 4.80 & 0.88 & 0.18 \\
\hline 0.35 & 0.21 & 4.30 & 0.92 & 0.10 \\
\hline Total & $\underline{\mathbf{0 . 2 2}}$ & 4.48 & $\underline{\mathbf{0 . 8 7}}$ & 4.78 \\
\hline
\end{tabular}

\begin{tabular}{|c|c|c|c|c|}
\hline \multirow{2}{*}{$\mathbf{H} / \mathbf{L}$} & \multicolumn{4}{|c|}{$\mathbf{Z = 2 0}$ meter } \\
\cline { 2 - 5 } & rata-rata a/c & $\mathbf{C V}$ & rata-rata b/c & $\mathbf{C V}$ \\
\hline 0.08 & 0.26 & 6.67 & 0.76 & 2.96 \\
\hline 0.10 & 0.26 & 5.89 & 0.75 & 0.69 \\
\hline 0.13 & 0.27 & 3.89 & 0.81 & 0.33 \\
\hline 0.15 & 0.27 & 6.02 & 0.78 & 0.63 \\
\hline 0.17 & 0.27 & 3.91 & 0.82 & 0.31 \\
\hline 0.18 & 0.26 & 3.26 & 0.85 & 0.19 \\
\hline 0.23 & 0.26 & 3.24 & 0.86 & 0.19 \\
\hline 0.25 & 0.28 & 3.96 & 0.85 & 0.28 \\
\hline 0.35 & 0.27 & 3.28 & 0.88 & 0.16 \\
\hline Total & $\underline{\mathbf{0 . 2 7}}$ & 1.50 & $\underline{\mathbf{0 . 8 2}}$ & 5.38 \\
\hline
\end{tabular}

Berdasarkan analisa besaran koefisien variasi dari banyak data rasio pemampatan yang diperoleh pada Tabel 1, maka dapat dilihat bahwa besarnya pemampatan tanah dasar di kaki timbunan terhadap tengah timbunan $(\mathrm{a} / \mathrm{c})$ adalah 0.22 dan besarnya ratio pemampatan tanah dasar di sisi timbunan terhadap tengah timbunan (b/c) adalah 0.87 pada kedalaman tanah lunak 10 meter (Gambar 11) . Sedangkan apabila kedalaman tanah lunak adalah 20 meter maka nilai $\mathrm{a} / \mathrm{c}$ adalah $0.27 \mathrm{dan} \mathrm{b} / \mathrm{c}$ adalah 0.82 (Gambar 12). Berdasarkan hasil analisa di atas maka diperoleh persamaan $\mathrm{y}=0.0047 \mathrm{x}+0.1729$ (untuk rasio a/c) dan $\mathrm{y}=-0.0046 \mathrm{x}+0.9121$ (untuk rasio $b / c)$ dimana $y=$ ratio dan $x=$ kedalaman tanah lunak mampu-mampat. Grafik untuk memperoleh persamaan tersebut dapat dilihat pada Gambar 13.

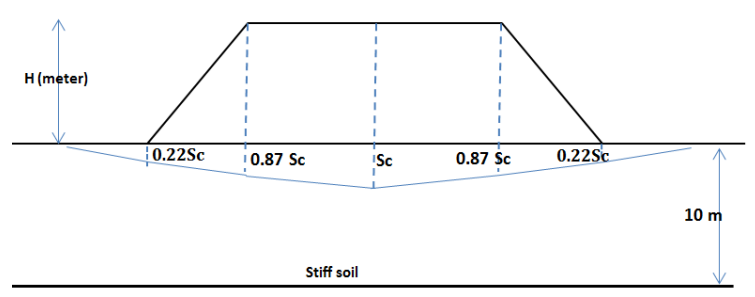

Gambar 11. Rasio pemampatan tanah di bawah timbunan pada kedalaman tanah lunak 10 meter

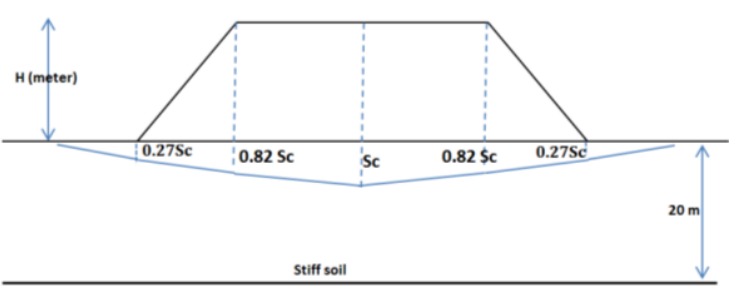

Gambar 12. Rasio pemampatan tanah di bawah timbunan pada kedalaman tanah lunak 20 meter 


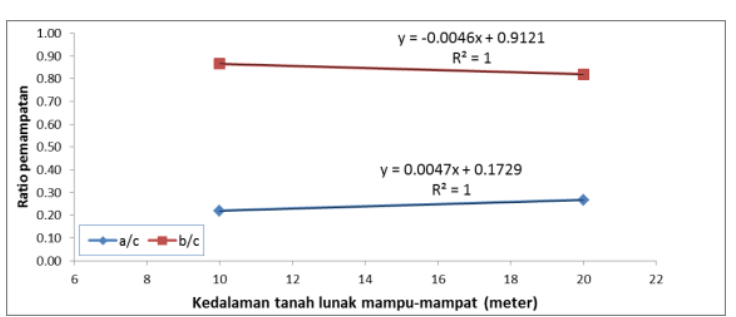

Gambar 13. Grafik hubungan ratio pemampatan dengan kedalaman tanah lunak.

\section{V.Kesimpulan dan saran}

\section{V.1 Kesimpulan}

Berdasarkan hasil analisa yang telah dilakukan pada berbagai variasi data tanah dan variasi beban timbunan di atasnya, maka diperoleh beberapa kesimpulan yaitu:

1. Besar pemampatan tanah dasar di kaki timbunan adalah tidak $=0$ sehingga pemampatan tanah dasar di area luar timbunan juga mungkin saja terjadi. Kondisi ini perlu dianalisa lebih lanjut terlebih lagi apabila area sekitar timbunan merupakan area yang pada penduduk.

2. Besar ratio pemampatan tanah dasar di kaki timbunan terhadap tengah timbunan adalah 0.22 untuk kedalaman tanah lunak 10 meter dan 0.27 untuk kedalaman tanah lunak 20 meter.

3. Besar ratio pemampatan tanah dasar di sisi timbunan terhadap tengah timbunan adalah 0.87 untuk kedalaman tanah lunak 10 meter dan 0.82 untuk kedalaman tanah lunak 20 meter.

\section{V.2 Saran}

Hasil penelitian ini menunjukan ratio pemampatan tanah dasar pada beberapa area tinjauan di bawah timbunan hingga memperoleh suatu rumusan empiris. Perlu dilakukan penelitian lanjutan untuk memverifikasi rumusan empiris yang diperoleh dalam penelitian ini dengan besarnya ratio pemampatan di lapangan menggunakan instrumen geoteknik.

\section{Daftar Pustaka}

Ardana.,M.,S.,Mochtar I.B.,(1999), "Pengaruh Tegangan Overburden Effective dan Platisitas Tanah Terhadap Kekuatan
Geser Undrained Tanah Lempung Berkonsistensi Sangat Lunak Sampai Kaku yang Terkonsolidasi Normal., Master Thesis Program Pasca Sarjana, Teknik Sipil ITS.

Azzouz.,A.S., R. J. Krizek, and R. B. Corotis,(1976), "Regression Analysis of Soil Compressibility", Soils and Foundations, 16(2),19-29.

Balasubramaniam.,AS.,H.Cai.,D.Zhu.,C.Surara $\mathrm{k}$ and E.Y.N.Oh.(2010),"Settlement of embankment in soft Soils", Geotechnical Engineering Journal of the SEAGS\&AGSSEA Vol.41 No.2 June 2010.

Kosasih.,A., Mochtar.,I.B.,(1997)., "Pengaruh Kadar Air, Angka Pori, dan Batas Cair Tanah Lempung Terhadap Indeks Pemampatan Konsolidasi Cc dan Indeks Pengembangan Cs., Master Thesis, Program Pasca Sarjana, teknik Sipil ITS.

Mesri.,G.A.,Godlewski.,P.M, (1977), “Time and Stress Compressibility Interrelationship", Journal of Geotechnical Enineering 103, 417-425.

Nagaraj, H.B., Sridharan.,A.(2004)., “ Coefficient of Consolidation and its Correlation With Index Properties of Remolded Soils", Geotechnical Testing Journal, 27(5).

Rendon-Herrero.,O., "Universal Compression Index Equation", (1980), Journal of the Geotechnical Engineering Division, American Society of Civil Engineering, 106(11), 1179-1200.

Sari,P.T.K, Firmansyah (2013)., "The Empirical Correlation Using Linear Regression of Compression Index for Surabaya Soft Soil".,Advances in Structural Engineering and Mechanics (ASEM13), Jeju,Korea.

Sari,P.T.K, Lastiasih Y (2015), "The empirical correlation using linear regression of settlement ratio under embankment load for Surabaya compressible soil", "Digital Proceeding of ICOCEECAPPADOCIA2015"

Sari,P.T.K, Lastiasih,Y.,(2015),’’Pengaruh Tinggi Timbunan Tanah Badan Jalan Terhadap Besarnya Perubahan

PuEnal STUDI ANALISA PENGARUH BEBAN TIMBUNAN TINGGI TERHADAP RATIO PEMAMPATAN TANAH DASAR 
Tegangan dan Pemampatan Tanah Dasar di Area Sekitar Timbunan", Prosiding Seminar Nasional Aplikasi Teknologi Prasarana Wilayah (ATPW) 2015, ISSN 2301-6752, A-39.

Skempton.,A.W.,(1944), "Notes on The Compressibility of Clays", J.Geo. Soc.London (C:parts 1\&2), 100, 119135.

Yoon.,G.,L., $\quad$ Kim.,D., $\quad$ Das.,S., Samui.,P,(2011).," Determination of Compression Index for Marine Clay : A Least Square Support Vector Machine Approach"., International Journal Advance Soft Computational Application., 3 (1), pp: 45-53.

Yan.,W.M, Yuen,K-V., $\quad$ Yoon,G.,L. (2009),"Bayesian Probabilistic Approach for The Correlations of Compression Index for Marine Clays", Journal of Geotechnical and Geoenvironmental Engineering ASCE, 1932-1940. 